\title{
West Sumatra Brown Rice resistance to Brown Planthopper and Blast Disease
}

\author{
INDRA DWIPA", AUZAR SYARIF, IRFAN SULIANSYAH, ETTI SWASTI \\ Department of Agronomy, Faculty of Agriculture, Andalas University. Limau Manis Campus, West Sumatra, Indonesia. \\ Tel.: +62-751-72701, Fax.: +62-751-72702, `email: 1965indradwipa@gmail.com \\ Manuscript received: 16 January 2018. Revision accepted: 22 April 2018.
}

\begin{abstract}
Dwipa I, Syarif A, Suliansyah I, Swasti E. 2018. West Sumatra Brown Rice resistance to Brown Planthopper and Blast Disease. Biodiversitas 19: 893-898. Brown rice is a highly nutritious rice widely consumed as the carbohydrate substitute of common rice. Brown rice resistance to biotic stress is one of indicators of a superior variety. Our study aimed to analyze the response of several brown rice genotypes from West Sumatra to brown planthopper attack and blast disease. This study comprised two experiments, the resistance assay to brown planthopper (Nilaparvata lugens (Stal.) and the resistance assay to blast fungi Pyricularia oryzae. The resistance assay to brown planthopper was done using randomized block design experiment with three replicates. Eighteen brown rice genotypes ( 15 brown rice, 2 black rice, and 1 control genotype) were tested in the assay. From 17 brown and black rice tested, 7 genotypes were resistant and 2 were moderately resistant. For blast resistance analysis, fifteen rice genotypes ( 13 brown rice and 2 black rice) were used. There was only 1 genotype highly resistant and 3 moderately resistant to blast disease among those 15 brown and black rice.
\end{abstract}

Keywords: Biotic stress, blast disease, brown planthopper, brown rice, West Sumatra

\section{INTRODUCTION}

Brown rice is a favorite rice among urban community. Brown rice is nutritious but has lower calory compared to common rice (Varshini et al. 2013). 100 grams of brown rice contain about $7.5 \mathrm{~g}$ protein, $0.9 \mathrm{~g}$ fat, $77.6 \mathrm{~g}$ carbohydrates, $16 \mathrm{mg}$ calcium, $163 \mathrm{mg}$ phosphorus, $0.3 \mathrm{~g}$ iron, $0.21 \mathrm{mg}$ vitamin $\mathrm{B} 1$, and anthocyanin (Pletch and Hamaker 2018). The awareness of people, especially that of the urban community, on healthy lifestyle results in an increase in the demand for brown rice annually (Babu et al. 2009). Indonesia is no exception, the increase is observed nationwide including in the Province of West Sumatra.

West Sumatra is a region in Indonesia that lies on the Earth's Equator and has a tropical rainforest climate. These conditions make the region rich in exotic genetic diversity resources. One of the important germplasms from West Sumatra is brown rice (Swasti 2004). Swasti et al. (2011) reported 10 local brown and black rice genotypes from West Sumatra. Putra et al. (2010) also reported 9 brown rice from Solok District, West Sumatra. Those reports indicate that West Sumatra possesses plenty of brown rice genotypes potential to be developed into superior rice varieties. One important indicator of a superior crop variety is the resistance to biotic stresses (Yaherwandi et al. 2013). Therefore, the goal of plant breeding program is to develop plant varieties resistant to stresses, pests and plant diseases. Current studies and explorations on local brown rice from West Sumatra barely give us a clear insight on the rice resistant to pests and diseases. Nurhasanah et al. (2018) stated that stress resistance traits of a rice plant are dictated by the genetic makeup of that plant. There is a specific interaction between the host plant and its pathogen in which the resistance gene can render resistance to the pathogen. This resistance to one pathogen is called vertical resistance or when it occurs to more than one pathogen it is called horizontal resistance (Fu et al. 2011; Sekhwal et al. 2015; Nurhasanah et al. 2018). Brown planthopper (Nilaparvata lugens (Stal.) is one of the most important pests that has been devastating rice crops, causing a significant yield loss. In West Sumatra, brown planthopper attacks caused a 100\% reduction in the rice yield (Taurislina 2015). Not only damage the plant, the brown planthopper is also a vector of rice virus such as rice grassy stunt virus and rice ragged stand virus (Cabauatan et al. 2009). Besides brown planthopper, the blast disease is the primary disease in rice (Babu et al. 2009). Blast disease is caused by Pyricularia oryzae Vac. (Hubert et al. 2015). In 2011 , blast disease affected 2,208 ha rice field in Indonesia, and increase to 3,649 in 2012 causing a yield loss between $50-90 \%$ in particular to susceptible rice varieties (Suriani et al. 2015). In cultivating brown rice, therefore, the loss of yield caused by these two plant pests must be carefully taken into consideration. The first step to generate a brown rice resistant to brown planthopper attack and blast disease is evaluating the tolerance of all available brown rice genotypes in West Sumatra to those pests. Our study aimed to identify local brown rice genotypes from West Sumatra that are resistant to brown planthopper attack and blast disease. 


\section{MATERIAL AND METHODS}

\section{Propagation of brown planthopper}

IR-42 rice seeds (a hopper-susceptible rice variety) were germinated on a seedbed $(30 \times 20 \times 5 \mathrm{~cm}) .15$ days after planting (DAP), rice plants were transferred to plastic pots (diameter $15 \mathrm{~cm}$; height $18 \mathrm{~cm}$ ) with 4 plants per pot. Urea fertilizer $(0.35 \mathrm{~g} / \mathrm{pot})$ was applied to 21 DAP-plant. At 30 DAP, rice plants were placed in an insect shield container made of wood covered with milar plastics materials. The base of the insect shield was covered with a sheet of plywood, and the top of the shield was covered with a gauze sheet. There were 5 insect shields $(60 \mathrm{x} 60 \mathrm{x}$ $60 \mathrm{~cm}$ ) and each shield contained 6 pots. 10 pairs of adult brown planthopper biotype 3 were placed inside the shield. The IR-42 rice plants were replaced weekly during the experiment (Yaherwandi et al. 2013).

\section{Rice resistance assay to brown planthopper}

A rice resistance assay to brown planthopper was done in the screen house and laboratory of Insect Bioecology, Department of Pest and Plant Diseases, Faculty of Agriculture, Andalas University, Padang, Indonesia. The experiment was conducted from October 2012 to January 2013. A Randomized Block Design was used in this experiment. 15 brown rice, 2 black rice genotypes together with 1 control genotypes were analyzed in this study. Each treatment group was prepared in triplicate. The 15 brown rice genotypes were Jorong Mudiak, Padi Ladang, Pido Manggih, Sikarujuik, Gunung pasir, Padi Telur, Surian, Teluk Embun, Kekuningan, Siarang, Pesisir Selatan, Talang Babungo, Sungai Abu, Perbatasan, and Capacino. The two black rice genotypes were Solok dan Beras Hitam Sariak Alang Tigo. Hopper-susceptible IR-42 rice was used as control genotype. All rice plants were grown in the screen house. Rice seeds were germinated on a seedbed (30 x 40 x $5 \mathrm{~cm}) .14$ DAP plants were transferred to pots (diameter $15 \mathrm{~cm}$; height $18 \mathrm{~cm}$ ), each pot was planted with 1 plant. Urea fertilizer $(0.35 \mathrm{~g} / \mathrm{pot})$ was applied to $21 \mathrm{DAP}$ plant. The resistance assay was performed on 30 DAP rice plants. Two parameters observed during the experiment were the rice resistance to brown planthopper and the lifetime of the brown planthopper.

\section{Level of rice resistance to brown planthopper}

One brown planthopper was transferred to each pot. Observation began when IR-42 rice started to show a hopper burn symptom. Rice resistant level was determined and classified based on the extent of plant damage as shown in Table 1. Data were analyzed using Duncan's New Multiple Range Test (DNMRT) at a significance level of $5 \%$.

\section{Rice resistance assay to blast disease}

The study was conducted in an area endemic of blast disease, Sitiung IV, Dharmasraya District, Province of West Sumatra, Indonesia from March to July 2013. 13 brown rice and 2 black rice genotypes were evaluated in this study. The thirteen brown rice genotypes were Jorong Mudiak, Padi Ladang, Pido Manggih, Sikarujuik, Gunung pasir, Padi Telur, Surian, Teluk Embun, Kekuningan, Siarang, Pesisir Selatan, Talang Babungo, Sungai Abu, Perbatasan, and Capacino. The two black rice genotypes were Solok and Sariak Alang Tigo. A Randomized Block Design was used in this experiment. The resistance assay was conducted in an experimental field of $350 \mathrm{~m}^{2}$. Each rice genotype was planted systemically in an alternating fashion between rows with a spacing of $20 \times 25 \mathrm{~cm}$. The experiment was done in triplicate, with the same sequence of the rice genotype in each replicate.

The observation was done every week on 40-60 DAP plants. Rice plant resistance assay to blast disease was performed following the protocol of IRRI (1996) (Table 2 and Figure 1). Data were analyzed using Duncan's New Multiple Range Test (DNMRT) at a significance level of $5 \%$.

\section{Lifetime of brown planthopper}

Gravid female brown planthoppers were transferred to the pot of each rice genotypes and then the lifetime of the hopper's nymphs was observed and recorded. Data were analyzed using Duncan's New Multiple Range Test (DNMRT) at a significance level of 5\%.

Table 1. Level of rice resistance to brown planthopper

\begin{tabular}{|c|c|c|c|}
\hline Score & Symptoms & Range & $\begin{array}{c}\text { Resistance } \\
\text { level }\end{array}$ \\
\hline 0 & No damage & - & $\begin{array}{l}\text { Highly } \\
\text { resistant }\end{array}$ \\
\hline 1 & $\begin{array}{l}\text { Mild damage, yellow lines } \\
\text { appears on the first leaf }\end{array}$ & $\geq 1-3$ & Resistant \\
\hline 3 & $\begin{array}{l}\text { The first and second leaves } \\
\text { yellow }\end{array}$ & $\geq 3-5$ & $\begin{array}{l}\text { Moderately } \\
\text { resistant }\end{array}$ \\
\hline 5 & $\begin{array}{l}\text { The leaves yellow, growth } \\
\text { inhibited, wilted, and half of } \\
\text { the plants are dead }\end{array}$ & $\geq 5-7$ & $\begin{array}{l}\text { Moderately } \\
\text { susceptible }\end{array}$ \\
\hline 7 & $\begin{array}{l}\text { More than } 50 \% \text { of the plants } \\
\text { are dead, and the rest are alive } \\
\text { but the growth is stunted }\end{array}$ & $\geq 7-9$ & Susceptible \\
\hline 9 & All plants are dead & $\geq 9$ & $\begin{array}{l}\text { Highly } \\
\text { susceptible }\end{array}$ \\
\hline
\end{tabular}

Source: International Rice Research Institute (IRRI) (1988)

Table 2. Scoring of rice plant resistance to blast disease (based on the shape and color change of the plant (IRRI 1996)

\begin{tabular}{lll}
\hline Score & Blast disease symptoms & Resistance \\
\hline 0 & $\begin{array}{l}\text { No symptoms } \\
\text { Small brown spots the size of a needle tip; } \\
1\end{array}$ & $\begin{array}{l}\text { Highly } \\
\text { resistant } \\
\text { no sporulation }\end{array}$ \\
3 & $\begin{array}{l}\text { Brown spots } 1-2 \mathrm{~mm} \text { in diameter; necrotic } \\
\text { sporulation }\end{array}$ & $\begin{array}{l}\text { Resistant } \\
\text { Small ellipse spots (3 mm x 2 mm) }\end{array}$ \\
5 & $\begin{array}{l}\text { Moderately } \\
\text { siamond-shaped spots with yellow, } \\
\text { brown, or purple margin } \\
\text { Overlapping diamond-shaped spots }\end{array}$ & $\begin{array}{l}\text { Susceptible } \\
\text { Highly } \\
\text { susceptible }\end{array}$ \\
\hline
\end{tabular}




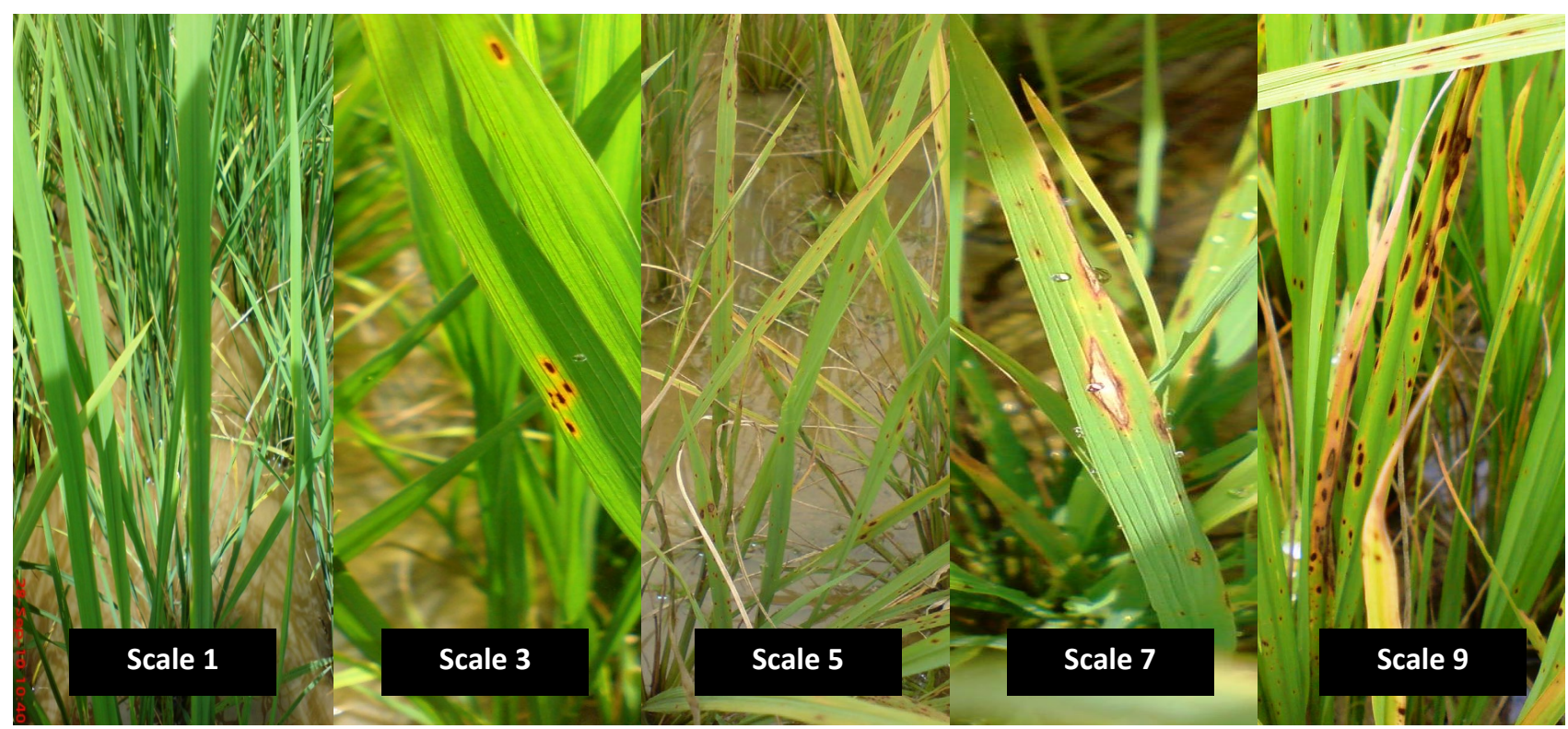

Figure 1. Symptoms and scoring of blast disease effect in rice plant

\section{RESULTS AND DISCUSSION}

\section{Rice resistance assay to brown planthopper}

Rice resistance to brown planthopper can be assayed by observing the extent of damage suffered by the plant upon the insect attack. Our result showed that there are 8 moderately resistant, 7 resistant, and 2 moderately susceptible rice genotypes (Tabel 3 ). The difference in the resistance response of the 17 rice genotypes is probably due to the difference in the toxin or antibiotic produced by rice plant (Singh et al. 2017; Qiu et al. 2011). Plants produce substances such as alkaloids or other organic compounds that possess repellent effect to brown planthopper (Sodiq, 2009; Qiu et al. 2011).

The seven genotypes resistant to brown planthopper may have a relatively rigid stem and coarse leaf surface. Srivastava et al. (2014) stated that resistant and moderately resistant varieties have a rather hard stem and coarse leaf surface. The hard and coarse plant structure make the brown planthopper difficult to feed on the plant sap, which eventually leads to nymph death due to starvation. Potassium, Calcium, and Silicone are elements that contribute to the toughness of the plant cell wall structure (lignin and cellulose) (Yaherwandi et al. 2013).

A susceptible genotype corresponds to the lifetime of brown planthoppers that infest the plant. Brown planthoppers with the longest lifetime was observed in IR42 whereas the shortest was found in Sariak Alang Tigo genotype (Table 4). A resistant plant suppresses the development of pest insects and this property corresponds to plant defense mechanism. Sarao and Bentur (2016) stated that there are three mechanisms of plant resistance: antixenosis (preference and non-preference), antibiosis, and tolerance. We argue that the rice plants that were resistant to the hopper attack have high antibiosis compounds. This, in turn, led to the death of the nymphs in the early phase, abnormal nymph growth, low fecundity, and short lifespan. Previously, Sodiq et al. (2009) have reported insects death in their early developmental phase in resistant genotypes. This effect is presumably due to the presence of active chemical compounds produced by the plant that are toxic to the nymphs. Thus, it is crucial to study these active compounds in brown rice (Ashtiani 2012). Genetic factor affects the brown rice immunity to brown planthopper attack. Du et al. (2009) reported that a rice gene called Bph14 is able to activate salicylic acid, induce callose deposition and boost the trypsin inhibitor production. Altogether these responses suppress the hopper's appetite, inhibit their growth and decrease the hopper's lifespan. Wu et al. (2017) describe the function of another gene, BPH15, contributing for the resistance of rice to brown planthopper. Based on genetic analyses, six miRNAs profile of this gene regulate rice development and defense response to brown planthopper (Wu et al. 2017).

\section{Rice resistance assay to blast disease}

In this study, rice plant resistance to blast disease is determined based on its disease index. The disease index as standardized by IRRI (1988) represents the severity of blast disease impact on plant, i.e., the formation of blast spot and its extent. Our result indicates that the responses of the plants on blast disease are varied from susceptible to resistant (Table 5). This difference is influenced by many factors such as temperature, host gene activity, pathogen gene, and other environmental factors (Syakira et al. 2016; Kharisma et al. 2013; Titone et al. 2014). Solok black rice is the only genotype resistant to blast disease of all other genotypes (Table 5). Resistant rice plants usually have a higher silicate content in comparison with susceptible 
Table 3. Brown rice resistance to brown planthopper

\begin{tabular}{lll}
\hline Genotype & $\begin{array}{l}\text { Resistance } \\
\text { score }\end{array}$ & Resistance level \\
\hline Genotype IR-42 & $9,00 \mathrm{a}$ & Susceptible \\
(control) & $6,20 \mathrm{~b}$ & Moderately susceptible \\
BrR Jorong Mudiak & $6,20 \mathrm{~b}$ & Moderately susceptible \\
BIR Solok & $5,40 \mathrm{bc}$ & Moderately susceptible \\
BrR Padi Ladang & $5,40 \mathrm{bc}$ & Moderately susceptible \\
BrR Pido Manggih & $4,60 \mathrm{bcd}$ & Moderately susceptible \\
BrR Sikarujuik & $4,60 \mathrm{bcd}$ & Moderately susceptible \\
BrR Gunung Pasir & $4,60 \mathrm{bcd}$ & Moderately susceptible \\
BrR Padi Tlur & $4,20 \mathrm{bcd}$ & Moderately susceptible \\
BrR Surian & $4,20 \mathrm{bcd}$ & Moderately susceptible \\
BrR Teluk Embun & $4,20 \mathrm{bcd}$ & Moderately susceptible \\
BrR Kekuningan & $3,80 \mathrm{~cd}$ & Resistant \\
BrR Siarang & $3,80 \mathrm{~cd}$ & Resistant \\
BrR Pesisir Selatan & $3,40 \mathrm{~cd}$ & Resistant \\
BrR Talang Babungo & $3,40 \mathrm{~cd}$ & Resistant \\
BIR Sariak Alang Tigo & $3,00 \mathrm{~d}$ & Resistant \\
BrR Sungai Abu & $3,00 \mathrm{~d}$ & Resistant \\
BrR Perbatasan & $3,00 \mathrm{~d}$ & Resistant \\
BrR Capacino &
\end{tabular}

Note: Different letters indicate a significant difference $(\mathrm{P}>0.05)$. $B r R=$ Brown rice, $B l R=$ Black rice

Table 4. Lifespan of brown planthoppers in brown rice plants

\begin{tabular}{|c|c|c|}
\hline \multirow{2}{*}{$\begin{array}{l}\text { Genotype } \\
\text { IR-42 (Genotipe pembanding) }\end{array}$} & \multicolumn{2}{|c|}{ Lifespan (day) } \\
\hline & 12.40 & $\mathrm{a}$ \\
\hline BrR Kekuningan & 11.82 & $\mathrm{a}$ \\
\hline BrR Pido Manggih & 11.80 & $\mathrm{a}$ \\
\hline BrR Surian & 10.12 & $a b$ \\
\hline BrR Gunung Pasir & 9.61 & $a b c$ \\
\hline BIR Solok & 9.15 & $a b c$ \\
\hline BrR Talang Babungo & 8.32 & $a b c$ \\
\hline BrR Sikarujuik & 7.91 & $a b c$ \\
\hline BrR Sungai Abu & 7.82 & $a b c$ \\
\hline BrR Pesisir Selatan & 6.88 & $a b c$ \\
\hline BrR Padi Telur & 6.67 & $a b c$ \\
\hline BrR Capacino & 6.20 & $a b c$ \\
\hline BrR Padi Ladang & 5.14 & $a b c$ \\
\hline BrR Siarang & 5.00 & $a b c$ \\
\hline BrR Teluk Embun & 4.20 & $a b c$ \\
\hline BrR Jorong Mudiak & 2.60 & bc \\
\hline BrR Perbatasan & 2.40 & $\mathrm{bc}$ \\
\hline BlR Sariak Alang Tigo & 1.72 & $\mathrm{c}$ \\
\hline
\end{tabular}

Note: Different letter indicate a significant difference $(\mathrm{P}>0.05)$. $\mathrm{BrR}=$ Brown rice, $\mathrm{BIR}=$ Black rice

plants. Ashtiani et al. (2012) stated that silicate content in rice can protect cell walls from Pyricularia oryzae Vac. hyphae. High silicate content physically fortifies rice especially its epidermis cells . Thus, the blast fungus $P$. Oryzae cannot penetrate rice leaf tissue (Buck et al. 2008).

Blast fungi are transmitted via air, attached to leaf surface through water splash, and infect leaf and generate blast spots (Devi and Sharma 2010). Rice resistance to blast disease is determined by the defensive structure of leaves, such as the degree of cuticle wax layer, epidermis-
Table 5. Blast disease index of local brown rice genotypes

\begin{tabular}{|c|c|c|}
\hline Genotype & Disease severity & Resistance level*) \\
\hline BrR Surian & Severe & Susceptible \\
\hline BrR Padi Ladang & Severe & Susceptible \\
\hline BrR Perbatasan & Severe & Susceptible \\
\hline BrR Kekuningan & Severe & Susceptible \\
\hline BrR Sikarujuik & Moderately severe & Moderately susceptible \\
\hline BrR Sungai Abu & Moderately severe & Moderately susceptible \\
\hline BlR Sariak Alang Tigo & Moderately severe & Moderately susceptible \\
\hline BrR Gn. Pasir & Moderately severe & Moderately susceptible \\
\hline BrR Talang Babungo & Medium & Medium \\
\hline BrR Padi Telur & Medium & Medium \\
\hline BrR Teluk Embun & Medium & Medium \\
\hline BrR Jorong Mudiak & Medium & Moderately resistant \\
\hline BrR Pido Manggih & Medium & Moderately resistant \\
\hline BrR Siarang & Medium & Moderately resistant \\
\hline BIR Solok & Mild & Resistant \\
\hline
\end{tabular}

Table 6. Classification of local brown rice resistance level according to their origin

\begin{tabular}{|c|c|c|}
\hline Origin & Genotype & Resistance level \\
\hline \multirow{6}{*}{ Solok } & BrR Surian & Susceptible \\
\hline & BrR Padi Ladang & Susceptible \\
\hline & BrR Talang Babungo & Medium \\
\hline & BrR Sungai Abu & $\begin{array}{l}\text { Moderately } \\
\text { susceptible }\end{array}$ \\
\hline & BIR Sariak Alang Tigo & $\begin{array}{l}\text { Moderately } \\
\text { susceptible }\end{array}$ \\
\hline & BIR Solok & Resistant \\
\hline \multirow[t]{4}{*}{ South Solok } & BrR Siarang & $\begin{array}{l}\text { Moderately } \\
\text { susceptible }\end{array}$ \\
\hline & BrR Gunung Pasir & $\begin{array}{l}\text { Moderately } \\
\text { susceptible }\end{array}$ \\
\hline & BrR Perbatasan & Susceptible \\
\hline & BrR Kekuningan & Susceptible \\
\hline \multirow[t]{3}{*}{ Pasaman } & BrR Padi Telur & Medium \\
\hline & BrR Teluk Embun & Medium \\
\hline & BrR Jorong Mudiak & $\begin{array}{l}\text { Moderately } \\
\text { resistant }\end{array}$ \\
\hline \multirow[t]{2}{*}{ West Pasaman } & BrR Pido Manggih & $\begin{array}{l}\text { Moderately } \\
\text { resistant }\end{array}$ \\
\hline & BrR Sikarujuik & $\begin{array}{l}\text { Moderately } \\
\text { resistant }\end{array}$ \\
\hline
\end{tabular}

layering cuticle, epidermis cell structure, and the size, shape, and location of stomata and lenticels (Anushree et al. 2016; Soares et al. 2014). Another factor that determines plant resistance to blast disease is the pathogen itself (Verma et al. 2015). We found half of the tested genotypes has the potential to be infected by $P$. oryzae. This result indicates that $P$. oryzae pathogenicity can break the rice defense. Fukuta et al. (2014) stated that rice plant defense is influenced by the genetics of the plant and environmental factors. 
Favorable environmental conditions allow rapid growth of P. oryzae (Rajput et al. 2017). Bhat et al. (2013) stated that at around $20^{\circ} \mathrm{C}$, rice plants become more susceptible to blast disease. In addition, this situation exacerbates the transmission of the disease. According to the local statistics, the daily temperature at the study location was $21-33^{\circ} \mathrm{C}$ (Statistics of Dharmasraya District 2013). Suryadi et al. (2013) stated that the transmission of blast disease will occur much easier in an area with high humidity in comparison to that with dry condition.

Our study found that different rice genotypes from the same origin gave different resistant responses (Table 6). This difference is presumably due to the difference in the genetic makeup of each rice genotype. Genetic factor is the primary determinant of rice resistance to blast disease. Liang et al. (2016) reported pi66 gene that is able to control blast disease in rice. Fukuta et al. (2014) suggest that many of the wild rice exhibited resistance to blast disease. Different rice genotypes have different morphology (Azizi et al. 2015). This difference is contributed by the difference in the genetics of each rice and environment where it grows. Nurhasanah et al. (2018) reported that in some local rice varieties tested against multiple diseases, there has been a specific interaction between the rice and the pathogen. This interaction is regulated by genes that control the rice resistance. In susceptible genotype, pathogens are flourishing, while in resistant genotype where the plant has a mechanism to recognize and respond to pathogens, the pathogen's growth and propagation are suppressed.

\section{ACKNOWLEDGEMENTS}

We immensely thank the Dean of the Faculty of Agriculture, Andalas University, Padang, Indonesia for facilitating this research and all parties that have helped the completion of this project.

\section{REFERENCES}

Anushree PU, Naik RM, Sathbai RD, Gaikwad AP, Nimbalkar CA. 2016 Differential biochemical response of rice (Oryza sativa L.) genotypes against rice blast (Magnoporthe oryzae). Cogent Biol 2 (1):1-15.

Ashtiani FA, Kadir JB, Selamat AB, Hanif AHBM, Nasehi A. 2012. Effect of foliar and root application of silicon against rice blast fungus in MR219 rice variety. Plant Pathol 90 (2): 263-272.

Azizi P, Rafii MY, Mahmood M, Abdullah SNA, Hanafi MM, Nejat N, Latif MA, Sahebi M. 2015. Plos One. 10 (5): 1-15

Babu PD, Subhasree, Bhakyaraj R, Vidyalakshmi. 2009. Brown rice beyond the color reviving a lost health food. Amer Euras J Agron 2 (2): 67-72.

Buck GB, Korndorfer GH, Nolla A, Coelho L. 2008. Potassium silicate as foliar spray and rice blast control. Plant Nutr 31: 231-237.

Cabacautan PQ, Cabunagan RC, Choi IR. 2009. Rice viruses transmitted by brown planthopper Nilaparvata lugens Stal. INGER Genetic Resources Center IRRRI, Los Banos, the Philippines.

Devi S, Sharma GD. 2010. Blast Disease of Rice Caused by Magnaporthe grisea : A review. Biological and Environmental Sciences. 6(1): 144154

Du B, Zhang W, Liu B, Hu J, Wei Z, Shi Z, He R, Zhu L, Chen R, Han B, He Guangchun. Identification and characterization of Bph14, a gene conferring resistance to brown planthopper in rice. Agric Sci 106 (52): 22.163-22.168
Fu J, Liu H, Li Y, Yu H, Li X, Xiao J, Wang S (2011) Manipulating broad-spectrum disease resistance by suppressing pathogen-induced auxin accumulation in rice. Plant Physiol. 155: 589-602.

Fukuta Y, Koga I, Ung T, Sathya K, Kawasaki A, Koide Y, Kobayashi N, Obara M, Yadana H, Hayashi N. 2014. Pathogenicity of rice blast (Pyricularia oryzae Cavara) isolates from Cambodia. Japan Agric Res Quart 48 (2): 155-166.

Hubert J, Mabagala, RB, Mamiro, DP. 2015. Efficacy of selected plant extracts against Pyricularia oryzae causal agent of rice blast disease. Amer J Plant Sci 6: 602-611.

IRRI. 1988. Description for Mile Oryza sativa L. IRRI, Los Banos, the Philippines.

IRRI. 1996. Standard Evaluation System for Rice, $4^{\text {th }}$ Edition. Inger Genetic Resources Center, International Rice Research Institute [IRRI], Los Banos, the Philippines.

Kharisma SD, Cholil A, Qurata'Aini L. 2013. The resistance of several hybrid rice genotypes (Oryza sativa L.) to Pyricularia oryzae Cav. Causing blast disease on rice plant. Pest Dis 1 (2): 19-27.

Liang Z, Wang L, Pan Q. 2016. A new recessive gene conferring resistance against rice blast. Rice 9 (47): 1-6.

Nurhasanah, Mujiono K, Darma ES, Sunaryo W. 2018. Genetic resistance of local upland rice population from East and North Kalimantan, Indonesia against some important diseases. Australian J Crop Sci 12 (2): 326-334.

Pletsch EA, Hamaker BR. 2018. Brown rice compared to white rice slows gastric emptying in humans. Eur J Clin Nutr 72:367-373.

Putra S, Suliansyah I, Ardi. Exploration and characterization of brown rice germ plasm of Solok and South Solok district, West Sumatra. Indon Agron 3 (30): 134-152.

Qiu Y, Gou J, Jing S, Tang M, Zhu L, He G. 2011. Identification of antibiosis and tolerance in rice varieties carrying brown planthopper resistance genes. Entomologia Experimentalis et Applicata 141: 226231.

Rajput LS, Sharma T, Madhusudhan P, Sinha P. 2017. Effect of temperature on growth and sporulation of rice leaf blast pathogen Magnoporthe oryzae. Curr Microbiol Appl Sci 6 (3): 394-401.

Sarao PS, Bentur JS. 2016. Antixenosis and tolerance of rice genotypes against brown planthopper. Rice Sci 23 (2): 96-103.

Sekhwal M K, Li P, Lam I, Wang X, Cloutier S, You FM (2015) Disease resistance gene analogs (RGAs) in plants. Int J Mol Sci. 16(8): 19248-19290.

Singh I, Sarao PS, Sharma N. 2017. Antibiosis components and antioxidant defense of rice as mechanism of resistance to brown planthopper, Nilaparvata lugens (Stal). Cereal Res Commun 45 (2): 284-295.

Soares LCS, Raphael JPA, Bortolotto RP, Nora DD, Gruhn EM. 2014. Blast disease in rice culture. Brazilian J Appl Technol Agric Sci 7 (2): 109-119.

Sodiq M. 2009. Resistance of Plant to Pests. [Thesis]. Universitas Pembangunan Nasional, Surabaya. [Indonesia]

Srivastava D, Shamin, M, Khumar D, Pandey P, Khan NA, Singh KN. Morphological and molecular characterization of Pyricularia oryzae causing blast disease in rice (Oryza sativa) from North India. Intl J Sci Res Publ 4 (7):1-9.

Statistic of Dharmasraya District. 2013. Dharmasraya in Figures. Statistics of Indonesia, Jakarta.

Suryadi Y, Susilowati DN, Riana E, Mubarik NR. 2013. Managament of rice blast disease (Pyricularia oryzae) using formulated bacterial consortium. Emirate J Food Agric 25 (5): 349-357.

Suriani NL, Suprata DN, Sudana IM, Temaja IGRM. 2015. Antifungal activity of Piper canium against Pyricularia oryzae Cav. The cause of rice blast disease on rice. Biol Agric Healthcare 5 (8): 72-78.

Swasti E. 2004. Physiology and Transmission of Phosphorus Efficiency Characteristic of Gogo Rice Plant in Aluminium Stress. [Thesis]. Bogor Agricultural University, Bogor. [Indonesian]

Syakira N, Jack A, Chan CW. 2016. The effect of physical enviromental factors of on the development of in field rice blast disease incidence. Proceeding of International Conference on Agricultural and Food Engineering. Kuala Lumpur. 23 August 2016. [Malaysian]

Taurislina E, Trizelia, Yaherwandi, Hamid H. 2015. Diversity analysis of brown planthopper Nilaparvata lugens natural rod enemies in paddy rice ecosystem in West Sumatra natural enemies in paddy rice ecosystem; Proceeding of National Seminary and Workshop on Biodiversity Management, Conserve, and Enrich the Resources and its Utilization. Gadjah Mada University, Yogyakarta, 21 March 2015. [Indonesian] 
Titone P, Mongiano G, Tamborini L. 2015. Resistance to neck blast caused by Pyricularia oryzae in Italia rice cultivars. Plant Pathol 140 (4): 2-13.

Varshini VPA, Azhagu SK, Vijay PP. 2013. Brown Rice: Hidden nutrients. Biosci Technol 4 (1): 503-507.

Verma S, Choudhury, Saha P. 2015. Blast resistance design of structure Research in Engineering and Technology. 4 (13): 64-69.
Wu Y, Lu W, Hu L, Rao W, Zeng Y, Zhu L, He Y, He G. 2017. Identification and analysis of brown planthopper-responsive microRNAs in resistant and susceptible rice plants. Sci Rep 7 (8712): $1-15$.

Yaherwandi, Reflinaldon, Rahmadani A. 2013. Biology of Nilaparvata lugens Stall [Homoptera: Delphacidae] of four varieties of rice plant (Oryza sativa L.). Educat Biol. 1 (2): 9-17. 